\title{
Remembering David T. Lykken; Research: The Bogdanov Affair, Maternal Height and Twinning Tendencies; Insights, Anecdotes and Visions
}

\author{
Nancy L. Segal \\ Department of Psychology, California State University, United States of America
}

\section{Remembering David T. Lykken}

September 21, 2006 brought the following e-mail message from Dr. Thomas J. Bouchard, Jr.:

Sad news. David died over the weekend ... I have attached the New York Times story. We are all getting older, aren't we?

I have thought a lot about David Lykken since that day because of the important part he played during my time in Minnesota (1982-1991), working on the study of twins reared apart. Nearly 2 half-days (one for each twin) were reserved for twin assessments in his psychophysiology laboratory.

Dr Lykken's contributions to twin research were stellar. His studies of EEG spectra, mate selection, mental abilities, personality, attitudes and interests are widely cited. David also coined the term 'emergenesis' to describe genetically-based traits that do not run in families - traits that are influenced by complex gene configurations that show high resemblance in monozygotic (MZ) twins, but weak resemblance in dizygotic (DZ) twins. A list of David's publications is appended to this article. (Interestingly, he did not include his publications in his CV.) $\mathrm{He}$ left quite a legacy.

The New York Times acknowledged David's life and death in a respectful and informative obituary in its September 20, 2006 issue (see Carey, 2006). I received several copies from friends and colleagues, some of whom had no idea that I knew David, but assumed I would be interested because

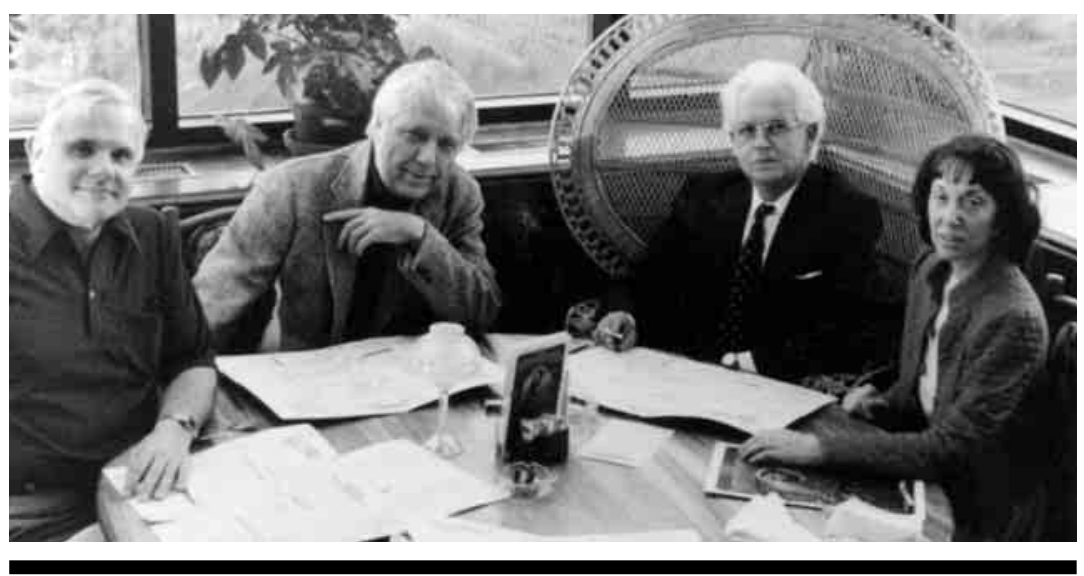

Drs Len Heston (left), David T. Lykken, Niels Juel-Nielsen and Elke D. Eckert at the University of Minnesota. (Photograph by Dr. Thomas J. Bouchard, Jr., University of Minnesota.)

twins were involved. Some information and excerpts from that piece form part of the life history that follows. I also provide my own recollections of David during my nine years as a postdoctoral fellow and research associate with the Minnesota Study of Twins Reared Apart. David is shown below with some other members of the reared apart research team and with visitor, Dr Niels Juel-Nielsen.

David T. Lykken was born on June 18, 1928, in Minneapolis. He and his wife, Harriet, had three sons: Jesse, Joseph and Matthew. Two of his sons are attorneys and one is a physicist, exemplifying David's view that talents have a partial genetic basis.

David's research career spanned more than 50 years and almost all of it took place at the University of
Minnesota. He earned a BA degree in psychology, philosophy and mathematics in 1949. As a psychology graduate student he held positions as an assistant in teaching (1949) and in research (1951), while earning an MA degree in psychology and statistics (1952). Next, he earned a PhD degree in clinical psychology, and neuropsychiatry (1955). His doctoral work, which examined individual differences in convicted criminals, found greater impulsivity and reduced fear in psychopaths, compared with other convicts or noncriminals. Aside from several academic residences in other institutions

Address for correspondence: Nancy L. Segal, Department of Psychology, California State University, Fullerton, CA 92834, USA. E-mail: nsegal@fullerton.edu 
(e.g., 1954-1955: NSF Fellow at the Maudsley Hospital, in London; 1959-1960: Fellow at the Center for Advanced Study at Stanford University; 1968-1969: NIMH Senior Fellow at the University of London), David's research took place at the University of Minnesota, Departments of Psychology and Psychiatry.

Over the years, David held a number of editorial and consulting positions. He was Editor for the Personality Research Monograph Series (1965-1985), Associate Editor of the Journal of Personality Research (1968-1974), Psychophysiology (1968-1974) and Physiological Psychology (1981-1986) and Consulting Editor for The Archives of General Psychiatry, Behavior Genetics, Science, and other journals. He consulted for private and governmental agencies, including Honeywell, Inc., the U.S. Air Force, NIMH, NSF and the Department of Defense Polygraphic Institute. He is famous for taking a strong stand against the use of the polygraph, which he believed was a 'flawed instrument and often implicated innocent people'.

David's signature line was a tribute to the scientific insights that can be gained from comparative studies of $\mathrm{MZ}$ and DZ twins. As quoted in the New York Times, 'Any research one might think of doing with human subjects is likely to be more interesting if you do it with twins'. I would add not just more interesting, but more informative. David did not just say this, he acted on it. He used twins creatively to show that mate selection may have a random basis. He used twins to show that shared environments have little effect on personality traits. He also used twins to show that each of us has a characteristic 'happiness set point', estimated to be $80 \%$ heritable. It is difficult to imagine how such findings could be demonstrated so persuasively without twins. Today, the 'happiness set point' has become part of the psychological jargon - as has 'emergenesis' (mentioned above). David's also coined the 'Rule of Two-Thirds' - the finding that most volunteer twin samples are comprised of two-thirds MZ twins and two-thirds female twins. It is impossible to remember these phrases and their associated concepts without remembering David Lykken ...

Production memory refers to the people, places and objects that we expect to see in certain locations, contexts and settings. We become keenly aware of them when they are absent. I have not been back to Minneapolis since 1996, so I have not experienced David's absence directly - but I have experienced it indirectly in a recent 'virtual tour' of his laboratory. Mostly, I remember the striking black and white photographs of twins on the walls. There was a picture displaying rows of twins' eyes and another displaying rows of their ears. These physical features are highly heritable and it was fascinating to examine the similarities and differences. There was also a photograph of identical male triplets, positioned so that the first triplet's face appeared to be above the second's - and the second's face appeared to be above the third's. One of the triplets was left-handed and his smiling mouth tilted slightly to the side opposite that of his two brothers. I think David once pointed this out.

One of my fondest memories of David was his response to two published student reviews of his book, Happiness: What Twin Studies Show Us About Nature, Nurture, and the Happiness Set Point (1999). In 2000, I offered California State University graduate students a final assignment option of reviewing a book we read in class; I submitted the best papers for publication in a professional society newsletter. That year two reviews were published, both in the ASCAP (Across Species Comparison of Psychopathology) Newsletter. David wrote back (edited slightly):

Nancy, thanks for sending me the nice reviews! The only two published reviews of that book originated in Fullerton! But ASCAP? Is that the American Society of Composers, Authors, and Publishers? (Lykken, 2000).

David was generous with his time when I taught that class. I sent him an e-mail indicating that the class was wondering what his explanation might be for the relatively lower heritability of the capacity for misery set point, on page 72 . His reply (edited slightly) is reproduced below:
I think this table illustrates both the virtues and the limitations of using these single item ratings. The 'abstract intelligence' item does wonderfully well, but people have had a lot of experience in assessing their own intelligence against that of others. But the 'contentment' item, one would have thought, should behave like the MPQ-Well Being (WB) score - but it doesn't. For $\mathrm{WB}$, the disattenuated MZ correlation would have been $<.95$ and the DZ correlation .10. So, I conclude that people can't really judge how they compare on contentment with people in general. And I think the same applies to 'Capacity for Misery' and 'Capacity for Happiness' - these single-item measures are good enough to suggest what goes with what, but not good enough to provide valid estimates of heritability. (Lykken, 1999).

Elsewhere in the book David provides practical counsel for people who want to raise their happiness levels, at least for the moment. He suggests focusing on small things that one really enjoys doing, noting that just the process of getting to a particular goal can be particularly pleasurable. He admits to a personal fondness for baking beer bread and lemon meringue pie, and even provides the recipes. One of my students put them to good use and arrived in class one day with the baked goods in hand. I took pictures of them and sent them to David. He was quite touched. When I glanced again through portions of his book, I learned that the last name 'Lykken' means 'the happiness' in Norwegian.

A symposium, 'It's Always Better With Twins: Remembering the Life and Research of David T. Lykken', will take place at the 2007 meeting of the International Society for Twin Studies, in Ghent, Belgium. Society members will have an opportunity to comment on David's life and work at that session.

\section{$\overline{\text { David T. Lykken }}$ Journal Publications}

David Lyken's paper, 'A more accurate estimate of heritability' was accepted for publication in this issue (pp. 168-173) shortly before his death.

Note: This list was drawn from public sources and may be incomplete. 
A more accurate estimate of heritability. Lykken, D. T. Twin Res Hum Genet. 2004; 10(1), 168-173.

The mechanism of emergenesis. Lykken, D. T. Genes Brain Behav. 2006; 5(4), 306-310. Review.

Parental licensure. Lykken, D. T. Am Psychol. 2001; 56(11), 885-894.

Reconstructing fathers. Lykken, D. T. Am Psychol. 2000; 55(6), 681-682.

The causes and costs of crime and a controversial cure. Lykken, D. T. $J$ Pers. 2000; 68(3), 559-605.

A behavioral genetic analysis of the relationship between the socialization scale and self-reported delinquency. Taylor, J., McGue, M., Iacono, W. G., Lykken, D. T. J Pers. 2000; 68(1), 29-50.

Individual differences in electrodermal responsivity to predictable aversive stimuli and substance dependence. Taylor, J., Carlson, S. R., Iacono, W. G., Lykken, D. T., McGue, M. Psychophysiology. 1999; 36(2), 193-198.

Incompetent parenting: Its causes and cures. Lykken, D. T. Child Psychiatry Hum Dev. 1997; 27(3), 129-137.

Personality and divorce: A genetic analysis. Jockin, V., McGue, M., Lykken, D. T. J Pers Soc Psychol. 1996; 71(2), 288-299.

Psychophysiological prediction of substance abuse. Iacono, W. G., Lykken, D. T., McGue, M. NIDA Res Monogr. 1996; 159, 129-149; discussion 150-160.

Genotype-environment correlations and interactions in the etiology of substance abuse and related behaviors. McGue, M., Lykken, D. T., Iacono, W. G. NIDA Res Monogr. 1996; 159, 49-72; discussion 73-80.

A genetic analysis of relative weight among 4020 twin pairs, with an emphasis on sex effects. Allison, D. B., Heshka, S, Neale, M. C., Lykken, D. T., Heymsfield, S. B. Health Psychol. 1994; 13(4), 362-365.

Heritability of interests: A twin study. Lykken, D. T., Bouchard, T. J. Jr, McGue, M., Tellegen, A. J Appl Psychol. 1993; 78(4), 649-661.

Is human mating adventitious or the result of lawful choice? A twin study of mate selection. Lykken, D. T., Tellegen, A. J Pers Soc Psychol. 1993; 65(1), 56-68.

Age and the self-perception of ability: a twin study analysis. McGue, M., Hirsch, B., Lykken, D. T. Psychol Aging. 1993; 8(1), 72-80.

Emergenesis. Genetic traits that may not run in families. Lykken, D. T.,
McGue, M., Tellegen, A., Bouchard, T. J. Jr. Am Psychol. 1992; 47(12), 1565-1577.

Why (some) Americans believe in the lie detector while others believe in the guilty knowledge test. Lykken, D. T. Integr Physiol Behav Sci. 1991; 26(3), 214-222.

Heterogeneity in the inheritance of alcoholism. A study of male and female twins. Pickens, R. W., Svikis, D. S., McGue, M., Lykken, D. T., Heston, L. L., Clayton, P. J. Arch Gen Psychiatry. 1991; 48(1), 19-28.

When kin correlations are not squared. Bouchard, T. J., Lykken, D. T., McGue, M., Segal, N., Tellegen, A. Science. 1990; 250(4987), 1498.

Sources of human psychological differences: The Minnesota Study of Twins Reared Apart. Bouchard, T. J. Jr, Lykken, D. T., McGue, M., Segal, N. L., Tellegen, A. Science. 1990; 250(4978), 223-228.

Does contact lead to similarity or similarity to contact? Lykken, D. T., McGue, M., Bouchard, T. J. Jr, Tellegen, A. Behav Genet. 1990; 20(5), 547-561.

Heritability of substance abuse and antisocial behavior: a study of monozygotic twins reared apart. Grove, W. M., Eckert, E. D., Heston, L., Bouchard, T. J. Jr, Segal, N., Lykken, D. T. Biol Psychiatry. 1990; 27(12), 1293-1304.

The Minnesota Twin Family Registry: some initial findings. Lykken, D. T., Bouchard, T. J. Jr, McGue, M., Tellegen, A. Acta Genet Med Gemellol (Roma). 1990; 39(1), 35-70.

Genetic and environmental influences on special mental abilities in a sample of twins reared apart. Bouchard, T. J. Jr, Segal, N. L., Lykken, D. T. Acta Genet Med Gemellol (Roma). 1990; 39(2), 193-206.

Genetic determination of the human EEG. Survey of recent results on twins reared together and apart. Stassen, H. H., Lykken, D. T., Propping, P., Bomben, G. Hum Genet. 1988; 80(2), 165-176.

Personality similarity in twins reared apart and together. Tellegen, A., Lykken, D. T., Bouchard, T. J. Jr, Wilcox, K. J., Segal, N. L., Rich, S. J Pers Soc Psychol. 1988; 54(6), 1031-1039.

Habituation of the skin conductance response to strong stimuli: A twin study. Lykken, D. T., Iacono, W. G., Haroian, K., McGue, M., Bouchard, T. J. Jr. Psychophysiology. 1988; 25(1), 4-15.
The within-pair EEG similarity of twins reared apart. Stassen, H. H., Lykken D. T., Bomben G. Eur Arch Psychiatry Neurol Sci., 1988; 237(4), 244-252.

Recruitment bias in twin research: the rule of two-thirds reconsidered. Lykken, D. T., McGue, M., Tellegen, A. Behav Genet. 1987; 17(4), 343-362.

Electrodermal activity in euthymic patients with affective disorders: One-year retest stability and the effects of stimulus intensity and significance. Iacono, W. G., Lykken, D. T., Haroian, K. P., Peloquin, L. J., Valentine, R. H., Tuason, V. B. J Abnorm Psychol. 1984; 93(3), 304-311.

Rhythmometry reveals heritability of circadian characteristics of heart rate of human twins reared apart. Hanson, B. R., Halberg, F., Tuna, N., Bouchard, T. J. Jr, Lykken, D. T., Cornelissen, G., Heston, L. L. Cardiologia. 1984; 29(5-6), 267-282.

Electrodermal activity in euthymic unipolar and bipolar affective disorders. A possible marker for depression. Iacono, W. G., Lykken, D. T., Peloquin, L. J., Lumry, A. E., Valentine, R. H., Tuason, V. B. Arch Gen Psychiatry. 1983; 40(5), 557-565.

The assessment of smooth tracking dysfunction. Iacono, W. G., Lykken, D. T. Schizophr Bull. 1983; 9(1), 44-50.

The effects of instructions on electrodermal habituation. Iacono, W. G, Lykken, D. T. Psychophysiology. 1983; 20(1), 71-80.

Measuring the average evoked response to light flashes: The contribution of eyeblink artifact to augmenting-reducing. Iacono, W. G., Gabbay, F. H., Lykken, D. T. Biol Psychiatry. 1982; 17(8), 897-911.

Presidential address, 1981. Research with twins: The concept of emergenesis. Lykken, D. T. Psychophysiology. 1982; 19(4), 361-373.

Diagnosis of zygosity in twins: Reply to Wilson. Lykken, D. T. Behav Genet. 1981; 11(6), 589-591.

Committee report. Publication recommendations for electrodermal measurements. Fowles, D. C., Christie, M. J., Edelberg, R., Grings, W. W., Lykken, D. T., Venables, P. H. Psychophysiology. 1981; 18(3), 232-239.

Two-year retest stability of eye tracking performance and a comparison of electro-oculographic and infrared recording techniques: Evidence of EEG in the electro-oculogram. 
Iacono, W. G., Lykken, D. T. Psychophysiology. 1981; 18(1), 49-55.

Measuring deviant eye tracking. Lykken, D. T., Iacono, W. G., Lykken, J. D. Schizophr Bull. 1981; 7(2), 204-205.

Blood typing and twin zygosity: A comparison of two methods. Lykken, D. T. Acta Genet Med Gemellol (Roma). 1981; 30(4), 293-295.

Comments on 'smooth-pursuit eye movements: A comparison of two measurement techniques' by Lindsey, Holzman, Haberman, and Yasillo. Iacono, W. G., Lykken, D. T. J Abnorm Psychol. 1979; 88(6), 678-680.

Eye tracking and psychopathology. New procedures applied to a sample of normal monozygotic twins. Iacono, W. G., Lykken, D.T. Arch Gen Psychiatry. 1979; 36(12), 1361-1369.

Electro-oculographic recording and scoring of smooth pursuit and saccadic eye tracking: A parametric study using monozygotic twins. Iacono, W. G., Lykken, D. T. Psychophysiology. 1979; 16(2), 94-107.

The orienting response: importance of instructions. Iacono, W. G., Lykken, D. T. Schizophr Bull. 1979; 5(1), 11-14.

The detection of deception. Lykken, D. T. Psychol Bull. 1979; 86(1), 47-53. Review.

Within-subject covariation of reaction time and foreperiod cardiac deceleration: Effects of respiration and imperative stimulus intensity. Iacono, W. G., Lykken, D. T. Biol Psychol. 1978; 7(4), 287-302.

The diagnosis of zygosity in twins. Lykken, D. T. Behav Genet. 1978; 8(5), 437-473.

The psychopath and the lie detector. Lykken, D. T. Psychophysiology. 1978; 15(2), 137-142.
Volunteer bias in twin research: The rule of two-thirds. Lykken, D. T., Tellegen, A., DeRubeis, R. Soc Biol. 1978; 25(1), 1-9.

Psychology and the lie detector industry. Lykken, D. T. Am Psychol. 1974; 29(10), 725-739.

On the validity of the preception hypothesis. Lykken, D. T., Tellegen, A., Psychophysiology. 1974; 11(2), 125-132. Review.

Genetic determination of EEG frequency spectra. Lykken, D. T., Tellegen, A., Thorkelson, K. Biol Psychol. 1974; 1(4), 245-259.

Range correction applied to heart rate and to GSR data. Lykken, D. T. Psychophysiology. 1972; 9(3), 373-379.

Perception: Autonomic response to shock as a function of predictability in time and locus. Lykken, D. T, Macindoe, I., Tellegen, A. Psychophysiology. 1972; 9(3), 318-333.

Schizophrenia and arousal revisited. Twoflash thresholds and electrodermal activity in activated and nonactivated conditions. Gruzelier, J. H., Lykken, D. T., Venables P. H. Arch Gen Psychiatry. 1972; 26(5), 427-432.

Direct measurement of skin conductance: A proposal for standardization. Lykken, D. T., Venables, P. H. Psychophysiology. 1971; 8(5), 656-672.

Square-wave analysis of skin impedance. Lykken, D. T. Psychophysiology. 1970; 7(2), 262-275.

Healthy scepticism. Lykken, D. T. Am J Psychiatry. 1970; 126(9), 1330.

Some properties of skin conductance and potential. Lykken, D. T., Miller, R. D., Strahan, R. F. Psychophysiology. 1968; 5(3), 253-268.

Statistical significance in psychological research. Lykken, D. T. Psychol Bull. 1968; 70(3), 151-159.
Autonomic versus cortical arousal in schizophrenics and non-psychotics. Lykken, D. T, Maley, M. J Psychiatr Res. 1968; 6(1), 21-32.

Correcting psychophysiological measures for individual differences in range. Lykken, D. T., Rose, R., Luther, B., Maley, M. Psychol Bull. 1966; 66(6), 481-484.

Psychological prediction from actuarial tables. Lykken, D. T., Rose, R. J Clin Psychol. 1963; 19, 139-151.

Perception in the rat: Autonomic response to shock as function of length of warning interval. Lykken, D. T. Science. 1962; 137, 665-666.

Confusion, conviction, and control groups. Lindzey, G., Lykken, D. T., Winston, H. D. J Abnorm Soc Psychol. 1961; 63, 221-222.

Continuous direct measurement of apparent skin conductance. Lykken, D. T., Roth, N. Am J Psychol. 1961; 74, 293-297.

Infantile trauma, genetic factors, and adult temperament. Lindzey, G., Lykken, D. T., Winston, H. D. J Abnorm Soc Psychol. 1960; 61, 7-14.

A rat-holder with electrodes for GSR measurement. Lykken, D. T, Rose, R. Am J Psychol. 1959; 72, 621-622.

Properties of electrodes used in electrodermal measurement. Lykken, D. T. J Comp Physiol Psychol. 1959; 52, 629-634.

A study of anxiety in the sociopathic personality. Lykken, D. T. J Abnorm Psychol. 1957; 55(1), 6-10.

Individual differences. Jenkins, J. J., Lykken, D. T. Annu Rev Psychol. 1957; 8, 79-112.

A method of actuarial pattern analysis. Lykken, D. T. Psychol Bull. 1956; 53(1), 102-107.

\section{Research: The Bogdanov Affair, Maternal Height and Twinning Tendencies}

\section{The Bogdanov Affair}

The identical Bogdanov twins, Igor and Grichka, were born in France, on August 29, 1949. They received PhD degrees from the University of
Bourgogne in different years - Igor specialized in theoretical physics (2002), while his brother specialized in mathematics (1999). The twins gained notoriety in the 1980s from their appearances on the French televi- sion programs, Temps $\mathrm{X}$ and Rayons $\mathrm{X}$, both of which address topics in popular science and science fiction. It is suspected that the Bogdanov twins' later association with possible scientific fraud and/or misrepresentation 
became more widely known because they were public figures from the start. The 'Bogdanov Affair' has many facets to it, so only a brief synopsis will be presented here, drawn from information available in Wikipedia (en.wikipedia.org/wiki/Bogdanov_Affair ). Individuals interested in additional details are invited to visit the website and links.

The controversy surrounding the twins seems to have begun when the cover of their 1991 book, Dieu at la Science (God and Science), indicated that both brothers held doctoral degrees when, in fact, they did not earn their degrees until 1999 and 2002. Charges of plagiarism also followed, but were settled out of court. Eventually, the scientific credibility of their articles, published subsequent to their receiving their PhD degrees, was questioned; in fact, both twins encountered difficulties in passing their final defense.

Over the next few years dialogues, debates and discussions about the twins appeared on the Internet and in major newspapers around the world. There is some support for the pair, but there is also considerable questioning of their scientific ability and integrity. Broader implications of the Bogdanov Affair concern the efficacy of the peer-review system in its present form, and what can be done to improve it. It could also be that this case attracted so much attention because it involved identical twins.

\section{Maternal Height and Twinning Tendencies}

A recent study by Steinman (2006b) linking maternal height and twinning tendencies drew considerable media interest. Specifically, evidence was presented to show that women whose height exceeded the United States population average (5.31 feet) were more likely to give birth to twins and triplets than relatively shorter women. (Women in the study had a mean height of nearly 5. 4 feet, range: 4.92 to 6.00 feet.)

The proposed underlying mechanism involves insulin-like growth factor (IGF), a substance that mediates the effects of growth hormone $(\mathrm{GH})$ on the body. In previous research, Steinman (2006a) showed that diet increased the bioavailability of intrafollicular IGF, enhancing follicular sensitivity to follicle stimulating hormone (FSH). He notes that the combination of $\mathrm{GH}$ with gonadatropin induces multiple ovulation in women experiencing fertility problems. Therefore, it was reasoned that if height and twinning are proportional to IGF level, then twinning might be correlated with height via IGF.

Steinman's (2006b) study is not the first one to find an association between maternal height and twinning tendencies. Several older studies reporting this result are summarized in MacGillivray et al. (1988), although a Scottish investigation found that the effect weakened with secular increases in maternal height. A concern with Steinman's (2006b) recent study is that the sample was quite modest in size $(n=129$ women). In addition, the proposed mechanisms responsible for the heighttwinning relationship predict an increase in DZ twin births only. The multiple birth children born to study participants included 'predominantly (but not exclusively) DZ sets' (Steinman, 2006b, p. 695). Precise figures were not provided, but would enable more accurate assessment of these findings, as would large-scale replication.

\section{Insights, Anecdotes and Visions}

\section{Fetus-in Fetu}

A case of the rare occurrence of fetusin-fetu was reported in a newborn Chilean boy (Reuters, 2006). Fetus-infetu describes a situation in which one twin becomes trapped within the other during pregnancy and continues to grow. In the latest case, the abnormality was identified by a scan shortly before the mother gave birth. Following delivery, the trapped fetus (which was four inches long and inside the newborn's abdomen) was removed. Fetus-in-fetu is estimated to occur in $1 / 500,000$ births. Less than 90 such occurrences have been reported worldwide.

\section{A Hidden Twin}

I came across a poster of Football Hall of Fame quarterback, John Elway, while looking through boxes of twin memorabilia sent by Kay Cassill (Twins Foundation). I
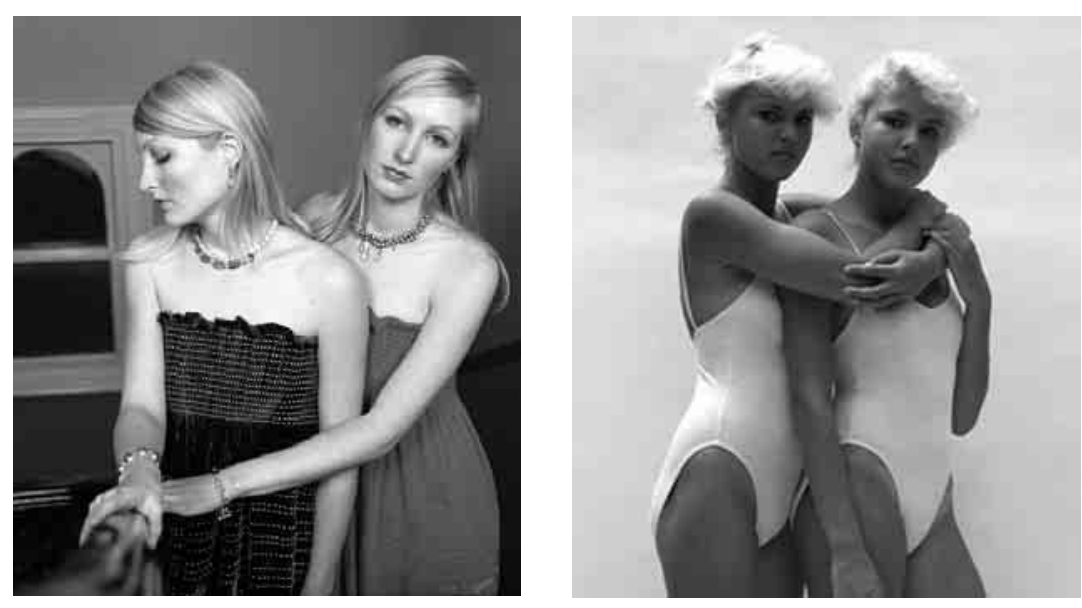

Identical twins. (Photo by Suellen Symons.)

learned that Elway had a twin sister who passed away from cancer, prompting him to donate research funds to the American Cancer
Society. 'My twin sister Jana meant the world to me. Growing up, she was my earliest playmate and sports competitor. Losing Jana hit me hard 
and I'd like to help to beat cancer any way I can' (FansEdge, 2004).

\section{Visions}

Pictures of $\mathrm{MZ}$ twins are continually fascinating. They remind us how much our physical development is influenced by genetic factors, while challenging our expectations of physical uniqueness across individuals. Two photographs taken by the talented Australian photographer, Suellen Symons, capture these concepts to perfection.

\section{References}

Carey, B. (2006, September 20). David Lykken, 78, dies; Studied behavior. New York Times, C-13.

FansEdge (2004). Elway home announces American Cancer Society will be official brand beneficiary. Retrieved from www.johnelway.com/news. aspx?id=8.

Lykken, D. (1999). Happiness: What twin studies show us about nature, nurture, and the happiness set point. New York: Golden Books Pub Co.

MacGillivray, I., Samphier, M., \& Little, J. (1988). Factors affecting twinning. In I. MacGillivray, D. M. Campbell, \&
B. Thompson (Eds.), Twinning and twins. Chichester: Wiley.

Reuters (2006). Chilean boy born with fetus in his stomach. Retrieved from www.reuters.com.

Steinman, G. (2006a). Mechanisms of twinning VII. Effect of diet and heredity on human twinning rate. Journal of Reproductive Medicine, 51, 405-410.

Steinman, G. (2006a). Mechanisms of twinning VIII. Maternal height, insulinlike growth factor and twinning rate. Journal of Reproductive Medicine, 51, 694-698. 